Canadian University Music Review

Revue de musique des universités canadiennes

\title{
Octatonicism and Chromatic Harmony
}

\section{Jean-Michel Boulay}

Volume 17, numéro 1, 1996

URI : https://id.erudit.org/iderudit/1014692ar

DOI : https://doi.org/10.7202/1014692ar

Aller au sommaire du numéro

\section{Éditeur(s)}

Canadian University Music Society / Société de musique des universités canadiennes

\section{ISSN}

0710-0353 (imprimé)

2291-2436 (numérique)

Découvrir la revue

\section{Citer cet article}

Boulay, J.-M. (1996). Octatonicism and Chromatic Harmony. Canadian University Music Review / Revue de musique des universités canadiennes, 17(1), 40-56. https://doi.org/10.7202/1014692ar
Résumé de l'article

In this paper, the author looks at the relationship between octatonic structures and chromatic harmony. The discussion concentrates on two major aspects of late-tonal octatonicism: the use of alternative bass tones for the diminished seventh chord and the development of these sonorities into hexachordal and pentachordal combination chords. A number of late nineteenth-century and early twentieth-century chromatic passages are analyzed. Complex harmonies in chromatic passages are explained by formulating reductive models comprised of simpler, octatonic constructs.
All Rights Reserved (C Canadian University Music Society / Société de musique des universités canadiennes, 1996
Ce document est protégé par la loi sur le droit d'auteur. L'utilisation des services d'Érudit (y compris la reproduction) est assujettie à sa politique d'utilisation que vous pouvez consulter en ligne.

https://apropos.erudit.org/fr/usagers/politique-dutilisation/ 


\title{
OCTATONICISM AND CHROMATIC HARMONY
}

\author{
Jean-Michel Boulay
}

For most musicians today, the words "octatonic" and "octatonicism" evoke the music of Stravinsky, Scriabin, and Messiaen. To these names, probably because of recent writings on the subject, some may add Liszt, RimskyKorsakov, and Debussy.

Octatonicism has been approached either historically or in a sui generis fashion. The confrontation between these two views of octatonicism has been growing ever since the publication, in 1983, of Pieter van den Toorn's book on the music of Stravinsky. ${ }^{1}$ In his book, van den Toorn, building on a theory developed by Arthur Berger, ${ }^{2}$ studied multiple facets of Stravinsky's octatonicism. He did not, however, specify the source of these practices, and thus implied that Stravinsky's use of the octatonic collection was totally original. In 1985, Richard Taruskin published his "Chernomor to Kashchei: Harmonic Sorcery; or, Stravinsky's Angle," 3 in which he attributed the shared paternity of octatonicism to Liszt and Rimsky-Korsakov. Taruskin, in order to show that nineteenth-century composers were interested in symmetric divisions of the octave, also cited examples from Beethoven's Sixth Symphony and from a few works of Schubert.

In another article, Taruskin expanded on his theory of Russian origins for octatonicism, citing examples by Rimsky-Korsakov, Borodin, and Steinberg. ${ }^{4}$ Van den Toorn's response attempted to cast doubt on Taruskin's "historical" approach. ${ }^{5}$ Van den Toorn simply refused to consider any octatonic practice prior to Stravinsky as worth mentioning. He finally argued that theorists do not need historical justification and base their judgments solely on their hearing and understanding. However, the problem of finding an origin for octatonicism-be it historical, geographical, or structural-still remains interesting.

Another approach to the problem may be found in a recent essay by Allen Forte on Liszt's experimental idiom. Forte analyzes many passages of distinctive octatonic character, writing that this aspect of Liszt's music is "relevant to further research," and adding that "study of the experimental music with

1 Pieter C. van den Toorn, The Music of Igor Stravinsky (New Haven: Yale University Press, 1983).

2 Arthur Berger, "Problems of Pitch Organization in Stravinsky," in Perspectives on Schoenberg and Stravinsky, edited by Benjamin Boretz and Edward T. Cone (New York: W.W. Norton, 1972).

3Richard Taruskin, "Chernomor to Kashchei: Harmonic Sorcery; or, Stravinsky's 'Angle," Journal of the American Musicological Society 38, no. 1 (1985): 72-142.

4Taruskin, "Chez Petrouchka: Harmony and Tonality chez Stravinsky," 19th-Century Music 10, no. 3 (1987): 265-86.

5Van den Toorn, “Taruskin's Angle," In Theory Only 10, no. 3 (1987): $27-46$. 
effective analytical method may illuminate certain facets of the more traditional diatonic music ... where we find structures supposedly endemic to the experimental idiom appearing in the traditional language." 6 This is also the case with many other composers of the second part of the nineteenth century, Richard Strauss among them. ${ }^{7}$

To understand the development of octatonicism, one has to realize that the "octatonic sound" was something that probably existed long before Stravinsky and Rimsky-Korsakov and in regions quite remote from Moscow or Saint Petersburg. Indeed, the octatonic aspects of some tonal music of the beginning of this century may be shown to have their origin in features inherent to traditional tonal harmony as practised by composers of the first half of the nineteenth century.

In this article, two main categories of tonal octatonic practice will first be identified. Then, ways of creating octatonic structures in tonal-chromatic contexts will be presented. Finally, a few octatonic passages from Richard Strauss's Salome will be analyzed.

\section{Decorative v. Structural Octatonicism}

It is possible to divide tonal octatonic practices into two general categories. The first will be called "decorative" and the second "structural." A specimen of decorative octatonicism is shown in example 1. It is the beginning of Olivier Messiaen's fifteenth Regard sur l'Enfant-Jésus, "Le Baiser de l'Enfant-Jésus." The excerpt is clearly in F-sharp major. The underlying harmony is very simple and consists of only four scale steps: I, V, IV, and II. Example 2 is a hypothetical rewriting of the passage without octatonic decorations.

A comparison between examples 1 and 2 shows how the fundamental harmonies are coloured (or ornamented) by means of the octatonic collection. Messiaen uses the three possible forms of that collection, which he calls "second mode à transpositions limitées," with their specific spellings: (C, C-sharp, D-sharp, E, F-sharp, G, A, A-sharp) is used with the tonic harmony (as in measures $1,3,5,11,13$, and 15); its transposition up a semitone, (C-sharp, D, E, E-sharp, G, G-sharp, A-sharp, B) is used with the dominant (as in $\mathrm{mm} .2,4$, and on the last beat of 14); and its transposition up a whole tone, (C, D, D-sharp, E-sharp, F-sharp, G-sharp, A, B), with the dominant preparations (as in mm. 12 and 14).

Examples of structural octatonicism will be presented below. The division of octatonic practice into two categories has a number of distinct theoretical advantages. For example, the controversy about the "origin" of octatonicism would most probably benefit from a careful examination of the type of octatonic writing used in the examples discussed by van den Toorn and Taruskin. One would probably realize that many of these examples, especially the early

6Allen Forte, "Liszt's Experimental Idiom and Music of the Early Twentieth Century," 19th-Century Music 10, no. 3 (1987): 209-28.

7Forte has done a magistral study of Debussy's octatonic practice in "Debussy and the Octatonic," Music Analysis 10, nos. 1/2 (1991): 125-69. 

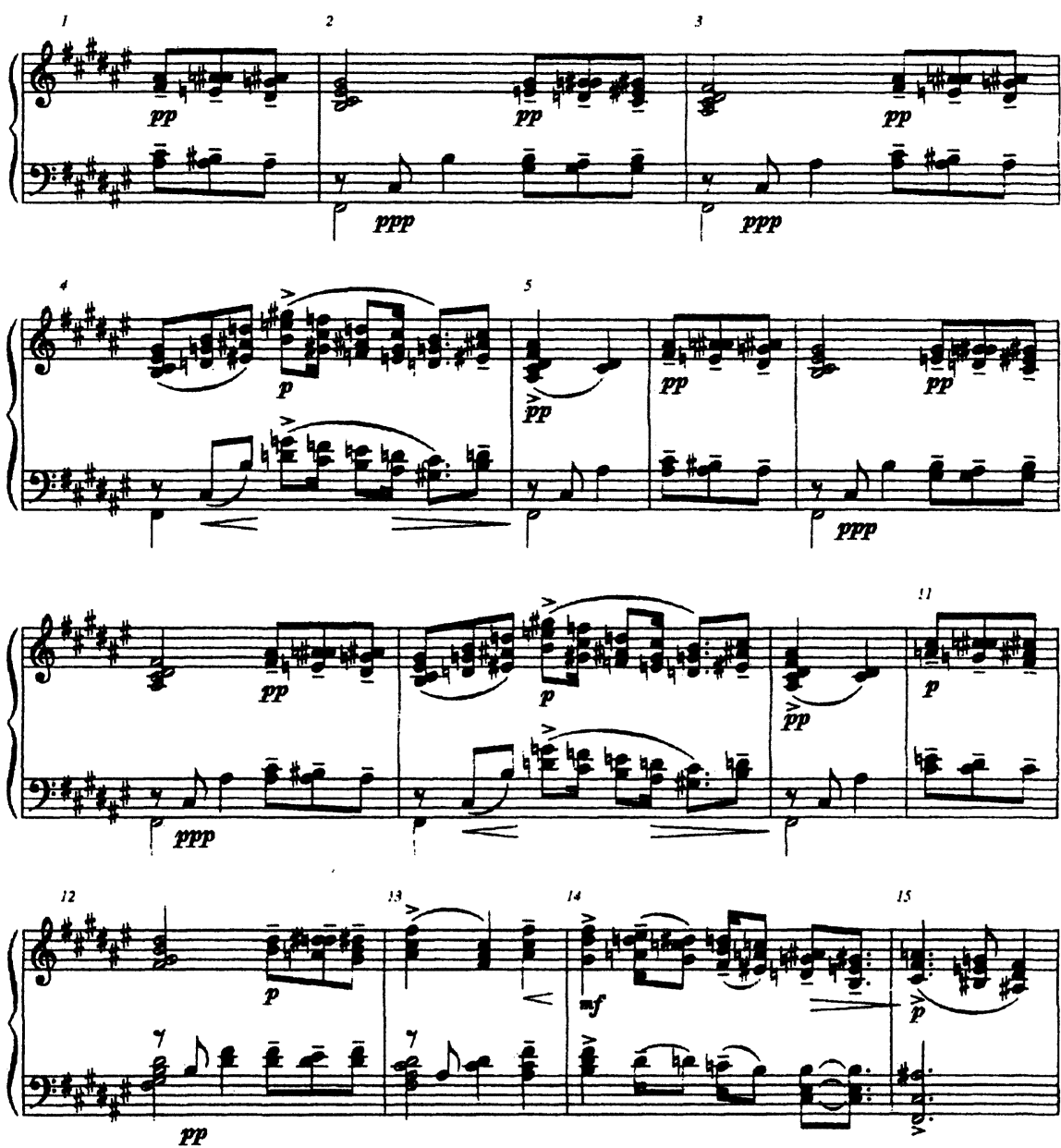

Example 1: Olivier Messiaen, Vingt Regards sur l'Enfant-Jésus, no. 15: "Le Baiser de l'Enfant-Jésus." (C) 1947 by Editions Durand, Paris, avec l'aimable autorisation de l'éditeur. Reproduction interdite.

Russian ones, are instances of decorative octatonicism and should not be included in the same discussions as examples of octatonicism of an organic type.

Because of its limited theoretical interest, decorative octatonicism will not be examined in greater detail here. The theoretical discussion that follows will concentrate, rather, on instances of octatonicism which are of structural importance and which are the result of the application of some standard tonal procedure or of a transformation of it. This is what could be called structural octatonicism.

\section{Structural Octatonicism and Chromatic Tonality}

In this section, different ways of projecting the octatonic collection in a tonal context will be explored. We will then concentrate on an important stage in the 

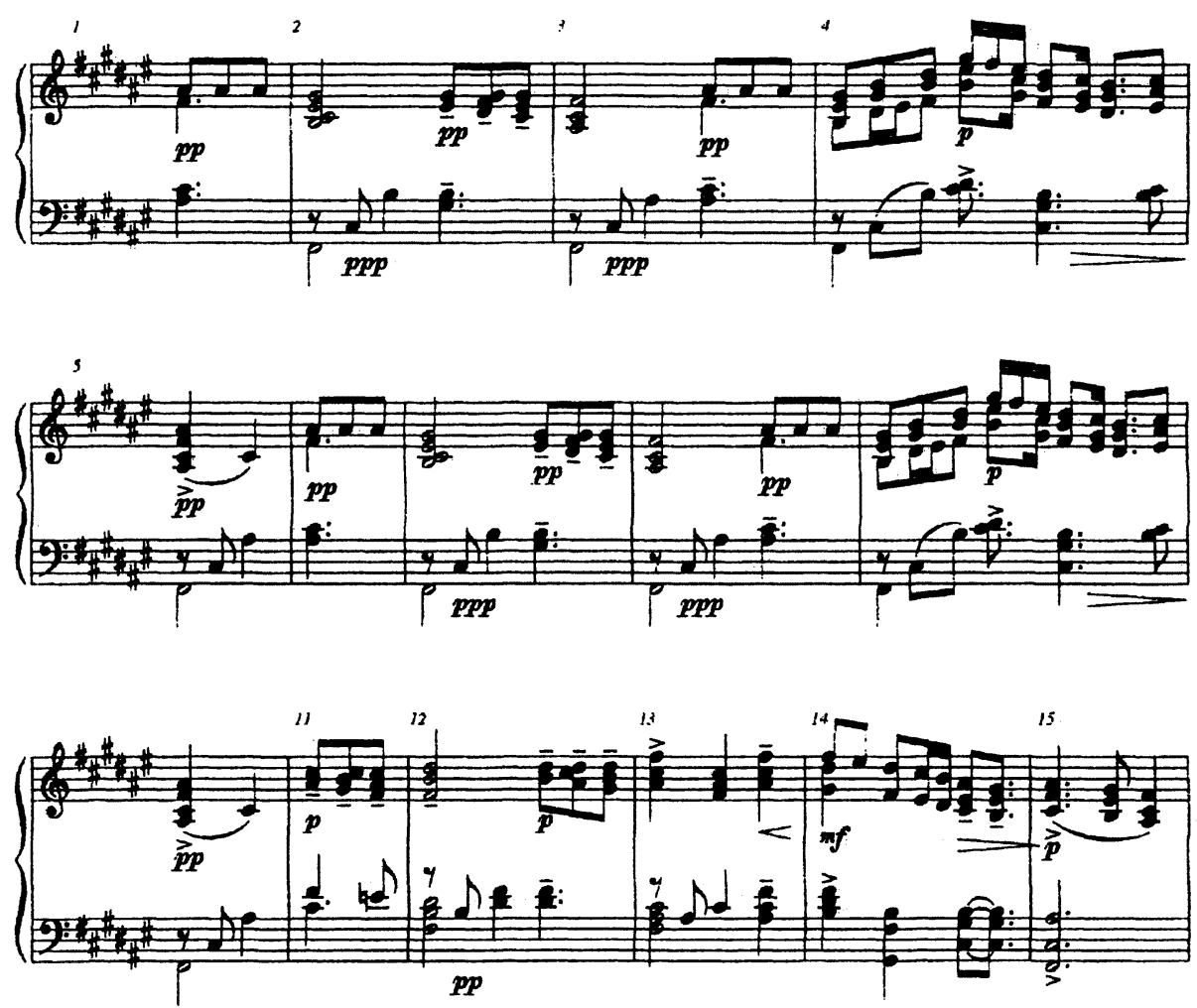

Example 2: Olivier Messiaen, Vingt Regards sur l'Enfant-Jésus, no. 15; hypothetical undecorated version.

development of the theoretical awareness of octatonic phenomena in chromatic tonality. This discussion will lead to an investigation of some sonorities of octatonic character often found in the music of the turn of this century, including Salome.

\section{The circle of fifths}

Root movement by descending fifth (or by ascending fourth) characterizes progressions of structural harmonies in tonal music. Especially important in this regard is the way of connecting a tonic chord to another tonic chord by the diatonic circle of fifths (I-IV-vii-iii-vi-ii-V-I).

A chromatic version of this progression is also possible, one which goes through the entire circle of fifths, with major triads on I, IV, VII, III, VI, II, IV, VII, III, VI, II, V, and I. In a recent article, Richard Cohn presents a very interesting example of this progression, taken from the second movement of Beethoven's Ninth Symphony. ${ }^{8}$ Figure 1 offers a four-stage model for the generation of this progression.

8Richard Cohn, "Properties and Generability of Transpositionally Invariant Sets," Journal of Music 


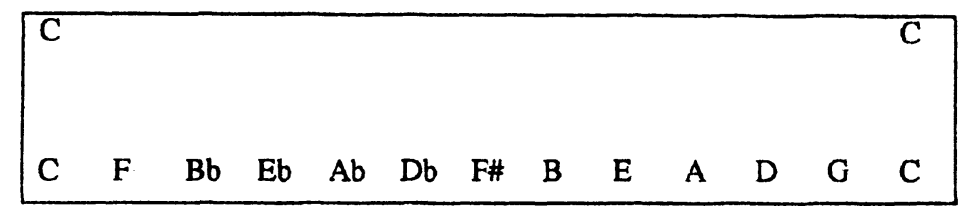

\begin{tabular}{|lllllllllllllllll|}
\hline $\mathrm{C}$ & & & $\mathrm{Eb}$ & & & $\mathrm{F} \#$ & & & $\mathrm{~A}$ & & & $\mathrm{C}$ \\
& & $\mathrm{Bb}$ & & & $\mathrm{Db}$ & & & $\mathrm{E}$ & & & $\mathrm{G}$ & \\
& $\mathrm{F}$ & & & $\mathrm{Ab}$ & & & $\mathrm{B}$ & & & $\mathrm{D}$ & & \\
$\mathrm{C}$ & $\mathrm{F}$ & $\mathrm{Bb}$ & $\mathrm{Eb}$ & $\mathrm{Ab}$ & $\mathrm{Db}$ & $\mathrm{F} \#$ & $\mathrm{~B}$ & $\mathrm{E}$ & $\mathrm{A}$ & $\mathrm{D}$ & $\mathrm{G}$ & $\mathrm{C}$ \\
\hline
\end{tabular}

\begin{tabular}{|c|c|c|c|c|c|c|c|c|c|c|c|c|}
\hline \multirow[t]{2}{*}{$\bar{C}$} & & $\bar{D}$ & $\mathrm{~Eb}$ & & $\bar{F}$ & $\overline{F \#}$ & & G\# & $\bar{A}$ & & $\bar{B}$ & $\bar{C}$ \\
\hline & A & $\mathrm{Bb}$ & & C & $\mathrm{Db}$ & & D\# & $\mathrm{E}$ & & F\# & G & \\
\hline$E$ & $F$ & & G & $\mathrm{Ab}$ & & A\# & B & & C\# & D & & $\mathrm{E}$ \\
\hline C & $F$ & $\mathrm{Bb}$ & $E b$ & $\mathrm{Ab}$ & $\mathrm{Db}$ & F\# & B & $\mathrm{E}$ & A & D & $G$ & C \\
\hline
\end{tabular}

\begin{tabular}{|lllllllllllll|}
\hline $\mathrm{C}$ & $\mathrm{C}$ & $\mathrm{D}$ & $\mathrm{Eb}$ & $\mathrm{Eb}$ & $\mathrm{F}$ & $\mathrm{F} \#$ & $\mathrm{~F} \#$ & $\mathrm{G} \#$ & $\mathrm{~A}$ & $\mathrm{~A}$ & $\mathrm{~B}$ & $\mathrm{C}$ \\
$\mathrm{G}$ & $\mathrm{A}$ & $\mathrm{Bb}$ & $\mathrm{Bb}$ & $\mathrm{C}$ & $\mathrm{Db}$ & $\mathrm{C \#}$ & $\mathrm{D} \#$ & $\mathrm{E}$ & $\mathrm{E}$ & $\mathrm{F} \#$ & $\mathrm{G}$ & $\mathrm{G}$ \\
$\mathrm{E}$ & $\mathrm{F}$ & $\mathrm{F}$ & $\mathrm{G}$ & $\mathrm{Ab}$ & $\mathrm{Ab}$ & $\mathrm{A \#}$ & $\mathrm{B}$ & $\mathrm{B}$ & $\mathrm{C \#}$ & $\mathrm{D}$ & $\mathrm{D}$ & $\mathrm{E}$ \\
$\mathrm{C}$ & $\mathrm{F}$ & $\mathrm{Bb}$ & $\mathrm{Eb}$ & $\mathrm{Ab}$ & $\mathrm{Db}$ & $\mathrm{F} \#$ & $\mathrm{~B}$ & $\mathrm{E}$ & $\mathrm{A}$ & $\mathrm{D}$ & $\mathrm{G}$ & $\mathrm{C}$ \\
\hline
\end{tabular}

Figure 1: Generation of a chromatic progression through the circle of fifths.

In stage 1 , the roots of the triads are given to the bass and the tonic is assigned to one of the three other voices, in this case to the soprano. In stage 2, one distributes the three different diminished-seventh chords (set 4-28) among the three upper voices, each voice receiving a different version of 4-28 and the notes being put in their respective columns, as determined by the bass voice. In stage 3, a leading tone (B) is generated in the soprano. The notes of the diminished-seventh chord (B, D, F, G-sharp) are then distributed to this voice so that they always precede the notes that were already set in stage 2 . The process is repeated in the alto (where B-flat is given a leading tone A) and tenor (where $F$ is given the leading tone $E$ ). Finally, in stage 4 , the blanks are filled by repeating the notes to their left (one should not forget that the last column is identical to the first one). Each column of the final matrix is an instance of set 3-11 (the triad) and each row a version of set 8-28, the octatonic collection.

This model is not only intellectually satisfying, it is also very interesting musically, since it offers us a chromatic circle of fifths of major triads with the

Theory 35 (1991): 1-32. The following model has been developed after a long discussion with Professor Cohn in 1987 . The idea of such a model was partly proposed by him. 
smoothest voice leading possible. In general, any attempt to write such a progression while preserving a smooth voice leading will result in the projection of the three possible octatonic scales. ${ }^{9}$ In example 3 , the soprano projects the collection (C, D, E-flat, F, G-flat, A-flat, A, B), the alto the collection (C, D-flat, E-flat, E, F-sharp, G, A, B-flat), and the tenor the collection (C-sharp, D, E, F, G, A-flat, B-flat, B).

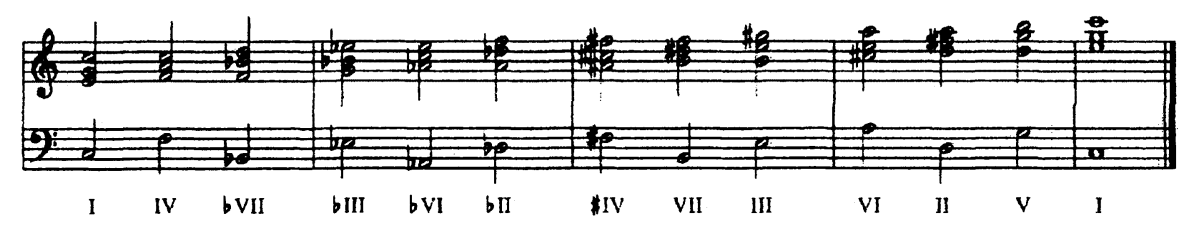

Example 3: Chromatic cycle of fifths, C major.

We now have a standard tonal progression with an accidental but distinctive octatonic character. There remains to be seen, however, how it can be used in musical situations. Because of its sequential nature, and because the fundamental melodic directions of tonal music are descending while these models have ascending lines, it should be encountered mostly in secondary events of connective character. This is exactly the case for the passage from Beethoven's Ninth Symphony presented by Cohn. In this excerpt, Beethoven uses part of the progression of example 3 to go from the tonic of $\mathrm{C}$ major to the dominant of $\mathrm{E}$ minor.

This example shows us that generation of the octatonic collection can be achieved through a perfectly normal harmonization of the circle of fifths and that composers were already using such tonal schemes at the beginning of the nineteenth century. European musicians did not have to wait for Glinka, Borodin, Mussorgsky, or Rimsky-Korsakov to generate occurrences of the octatonic collection.

\section{$\left(\begin{array}{llll}0 & 3 & 6 & 9\end{array}\right)$ division of the octave}

Elementary tonal-harmonic progressions possessing octatonic character can be generated by means of a division of the octave into four equal parts. The most simple of these progressions consists of a succession of four triads (major or minor) at a distance of a minor third. Such successions may be found both at the surface and at the middleground of many works of the second half of the nineteenth century. They are used nearly always as prolongational tools. This is the case, for example, with the closing measures of Johannes Brahms's song "Immer leiser wird mein Schlummer," Op. 105/2, mentioned by van den Toorn. ${ }^{10}$

9Since the octatonic scale is the result of the union of two diminished-seventh chords and since there are three different such tetrachords $(x, y$, and $z)$, there are only three different octatonic scales $(x+y, x+z, y+z)$.

10Van den Toorn, "Taruskin's Angle," In Theory Only 10, no. 3 (1987): 27-46. 
As can be seen in the analytical reduction of example 4, Brahms, who has begun his song in C-sharp minor, tonicizes scale-step III at measure 41 . There follows a succession of second-inversion major triads with the roots $\mathrm{G}$, B-flat, and D-flat. The latter is treated as a cadential $6 / 4$ chord. Finally, the song ends in the parallel key, D-flat major. Scale-step III is thus part of a III-V-I cadence in C-sharp (D-flat) major-minor. ${ }^{11}$

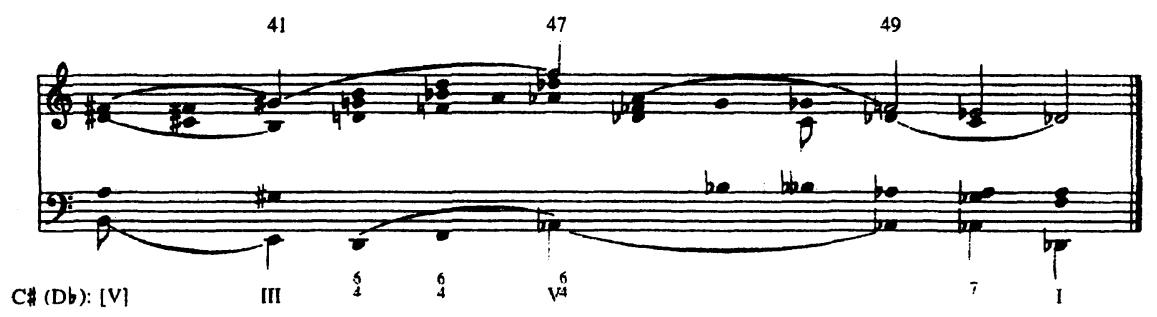

Example 4: Brahms, "Immer leiser wird mein Schlummer", Op. 105/2, mm. 40-53; analytical reduction.

Examples 5a and 5b present analytical reductions of $\mathrm{mm} .157$ to 181 of Chopin's Mazurka in C-sharp minor, op. 50/3. ${ }^{12}$ Here, we have a good example of multi-level utilization of octatonic progressions, with two successions of major triads at a distance of a minor third embedded in another such progression. The upper voice of the embedded progressions clearly projects the octatonic scale (F-sharp, G, A, A-sharp, B-sharp, C-sharp, D-sharp, E). After a perfect cadence on the tonic at $\mathrm{m} .155$ and a tonicization of $\mathrm{B}$ at $\mathrm{m} .159$, the dominant is reached through the minor-third chain B-D-F-G-sharp, in which the D major (m. 161) and G-sharp major (m. 169) triads are prolonged by secondary minor-third chains. The dominant triad receives a seventh at $\mathrm{m} .180$ and finally resolves to the tonic at $\mathrm{m}$. 181. In example 5a, applied dominants of the larger progression are notated in eighth notes and applied dominants of embedded progressions are notated in sixteenth notes.

11 One can use a simple and concise expression to describe the content of each chord of the progression in terms of two source diminished-seventh chords. For example, if $x$ is the ordered collection (E, G, B-flat, D-flat) and $y$ the ordered collection (F, A-flat, B, D), then the contents of each chord of the progression can be determined by the expression $\left\{x_{i}, y_{i+1}, y_{i+2}\right\}, 0$ i 3 . The subscripts represent order numbers and the addition operation is performed modulo 4 . Thus, for example, the first chord will contain the first element of $x$ and the second and third elements of $y$ (giving the chord E, G-sharp, B) and the third chord will contain the third element of $x$ and the fourth and first elements of $y$ (giving the chord B-flat, D, F). This notation can be used with many other progressions of the same type. For example, a succession of four minor triads at a distance of a minor third can be notated $\left\{x_{i}, x_{i+1}, y_{i+2}\right\}, 0$ i 3 . A similar succession of dominant seventh chords can be notated $\left\{x_{i}, y_{i+1}, y_{i+2}, y_{i+3}\right\}, 0$ i 3 . A succession of four minor triads with an added sixth (or half-diminished seventh chords) can be expressed as $\left\{x_{i}, x_{i+1}, x_{i+3}, y_{i+2}\right\}, 0 i 3$. Finally, a succession of four French-sixth chords will translate as $\left\{x_{i}, x_{i+2}, y_{i+1}, y_{i+3}\right\}, 0 i 3$. Many other similar progressions, not all of them usable in a tonal context, may be generated in this way, and elements of different progressions can be combined.

12Measures 161 to 165 are mentioned in Felix Salzer and Carl Schachter, Counterpoint in Composition (New York: McGraw Hill, 1969), 218. 

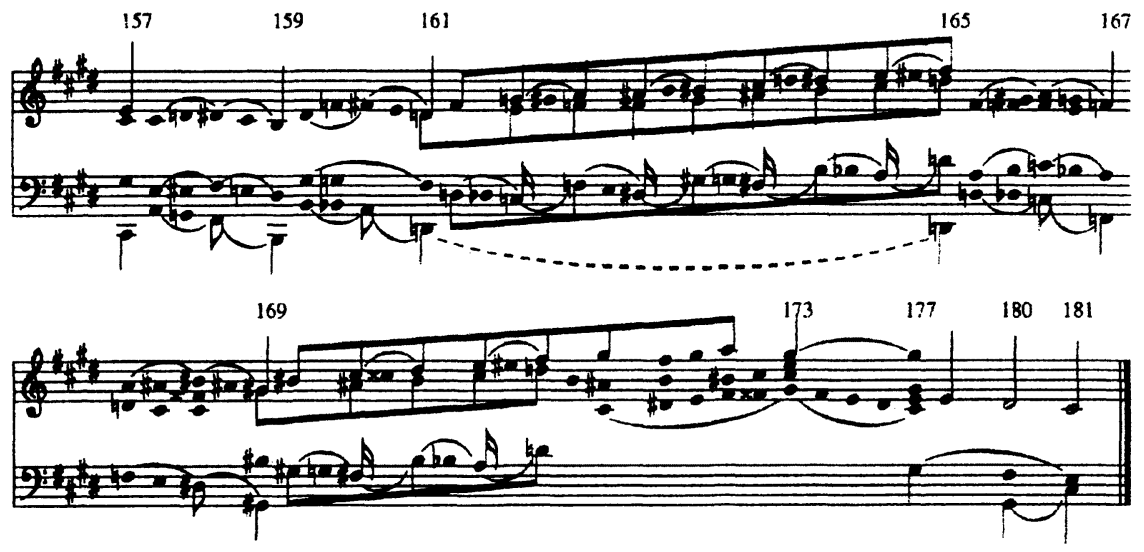

Example 5a: Chopin, Mazurka in C-sharp minor, Op. 50/3, mm. 157-81; analytical reduction.

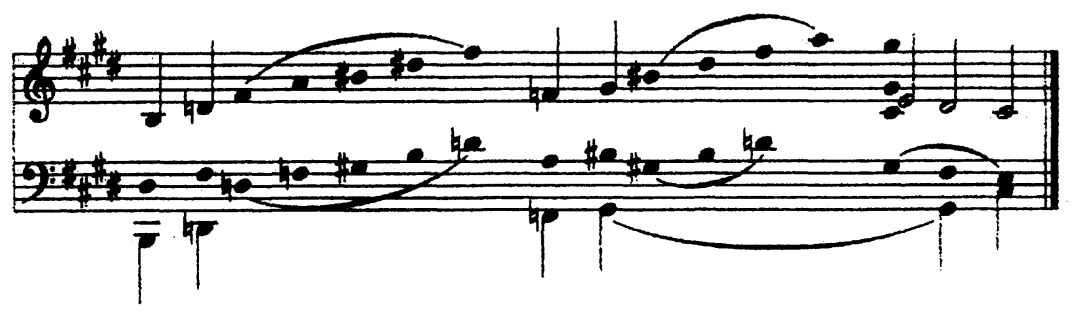

Example 5b: Chopin, Mazurka in C-sharp minor, Op. 50/3, mm. 157-81; middleground.

Let us now see how two of the progressions described above can be combined and give rise to new octatonic possibilities. Examples $6 \mathrm{a}$ and $6 \mathrm{~b}$ give two rising progressions of four major triads at a distance of a minor third. One begins on the root A-flat and goes through C-flat, D, and F, while the other begins on E-flat and continues with F-sharp, A, and C. The total collection for the first progression is (C, D, E-flat, F, F-sharp, G-sharp, A, B). That for the second is its transposition down two semitones, (C, D-flat, E-flat, E, F-sharp, G, A, B-flat).

Example 6c shows how the two progressions can be combined by interlocking. One can now decide to create a situation somewhat analogous to that of the Beethoven excerpt mentioned above and project the third octatonic collection, (C-sharp, D, E, F, G, A-flat, B-flat, B), in the upper voice. In order to do so, the triad on C-flat is interpreted as a VI chord, quickly transformed into a first-inversion mixture-sub-dominant chord, itself resolving to a new dominant triad on B-flat (as in the first system of example 6d) and the triad on D becomes a VI chord resolving on a new dominant triad on C-sharp (as in the second 


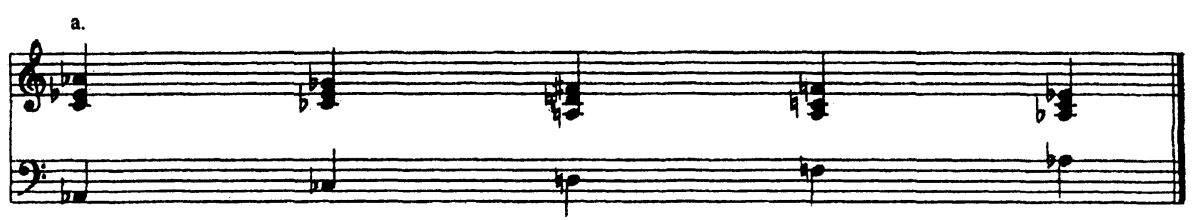

b.
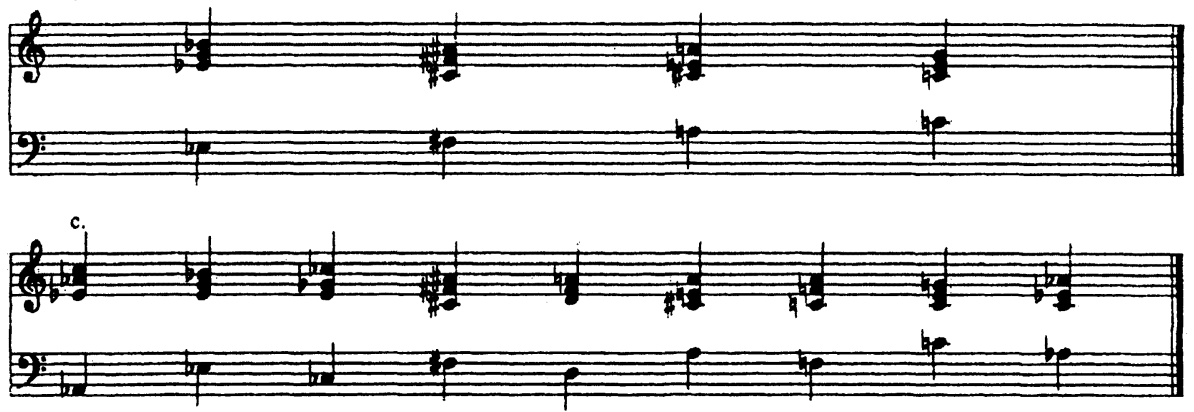

d.
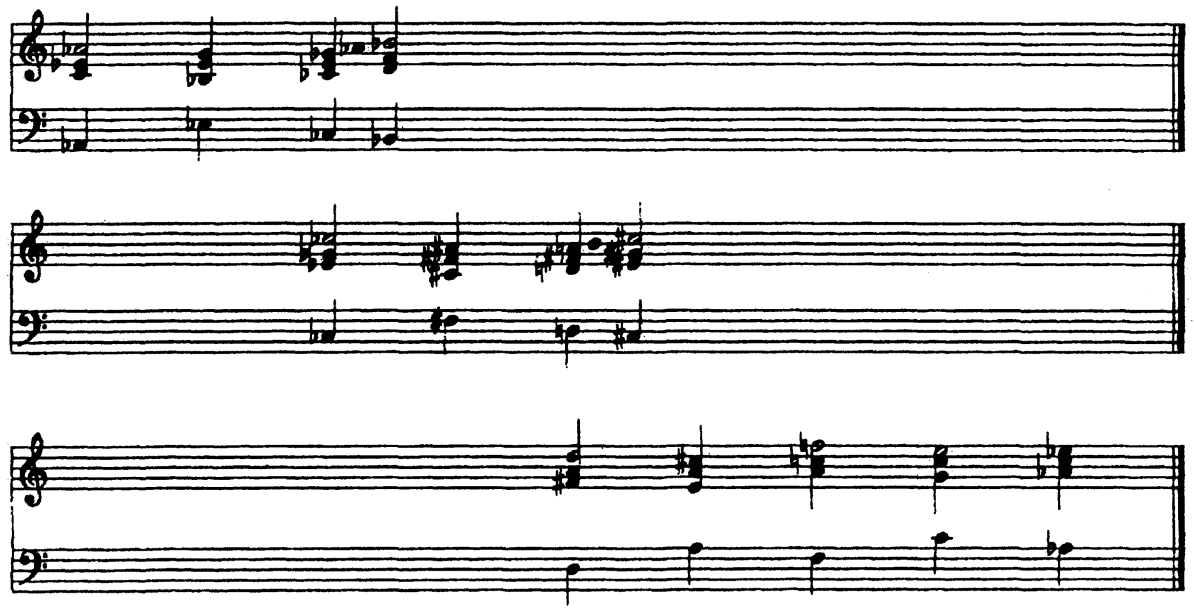

Example 6: Generation of a complex octatonic progression.

system of example $6 \mathrm{~d}$ ). The rest of the original progression remains unchanged. We thus have created the soprano line A-flat, B-flat, B, C-sharp, D, E, F. The total collection of that line is an instance of the only seven-element subset of the octatonic collection (set 7-31). Example 7 gives the beginning of the Liebestod from the third act of Wagner's Tristan und Isolde. It is also a realization of example $6 \mathrm{~d}$.

\section{Alternative Bass Tones for the Diminished Seventh Chord}

In the nineteenth chapter of his Harmonielehre, "Some additions and schematic presentations to round out the system," Arnold Schoenberg mentions a recurring harmonic device found in much music of the turn of the century, "espe- 

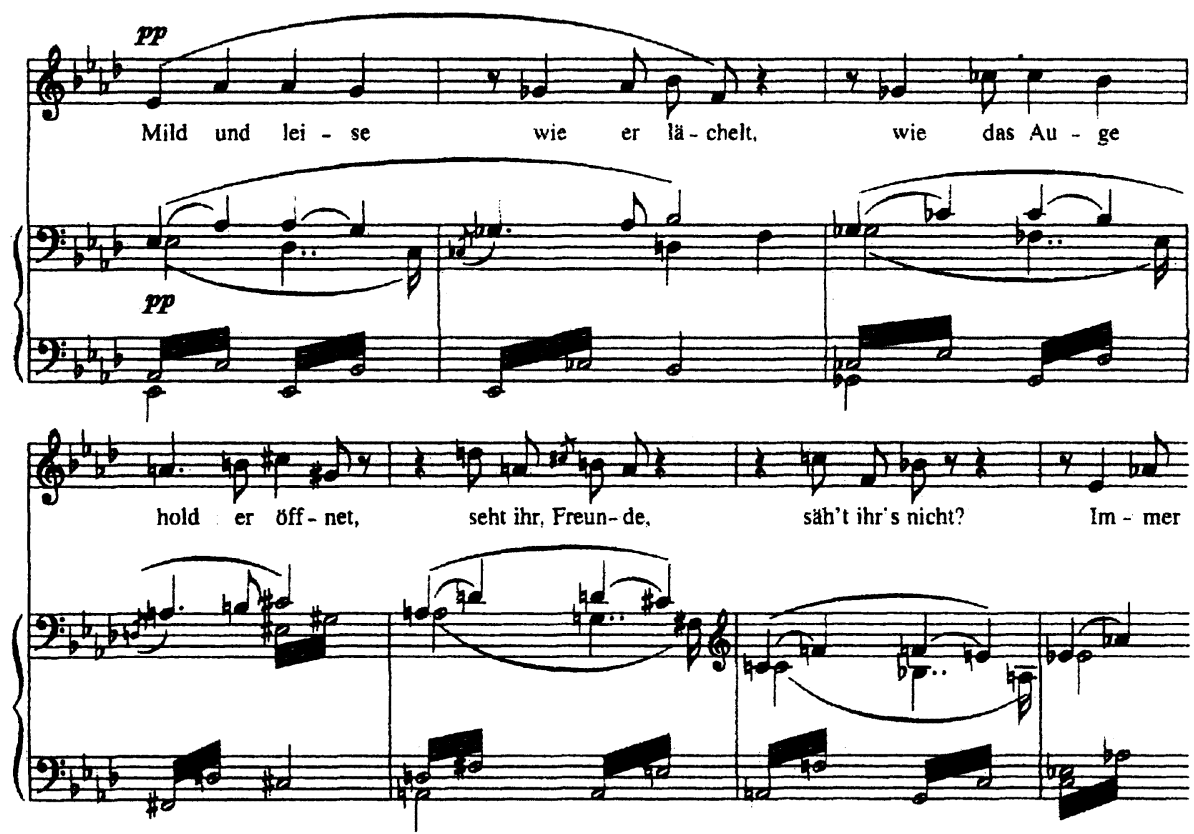

Example 7: Wagner, Tristan und Isolde, act 3, "Mild und leise."

cially in that of Richard Strauss": the use of notes from one diminished seventh chord as alternative bass tones for another diminished seventh chord. ${ }^{13}$ This of course generates dominant ninth chords with lowered sixth scale degrees in four different keys. Although these dominant ninth chords may either resolve in a normal manner to their respective tonics, as shown in example $8,{ }^{14}$ or be connected within one progression "if after each of the four we imagine a sufficiently long pause or an event that makes the reinterpretation possible," 15 one may also regard the four bass notes and the diminished seventh chord as a total entity. Schoenberg writes:

If we think it faster, however, or imagine the reinterpretation as direct, with no intermediary, then we will see how it is possible to play together with one diminished seventh chord a voice that consists of the four tones of a different diminished seventh chord.

Schoenberg also mentions the possibility of inserting the notes of the upper diminished seventh chord between those of the lower one to form a scale. The result of this procedure is of course the octatonic scale. He also alludes to the

13 Arnold Schoenberg, Theory of Harmony, translated by Roy E. Carter (Berkeley: University of California Press, 1978), 366-67.

14 Ibid., 381-82.

15 Ibid., 366. 


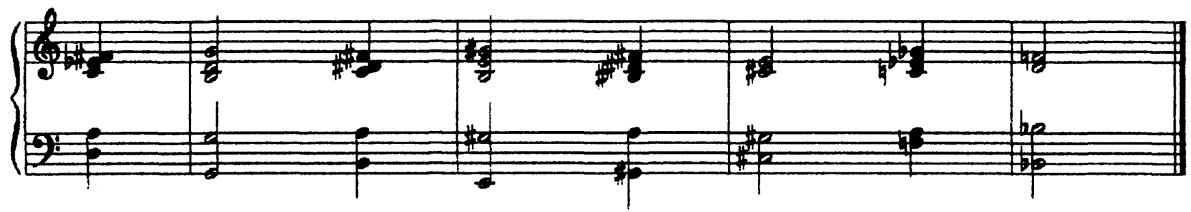

Example 8: Normal resolutions of dominant ninth chords.

possibility of having the third possible diminished seventh chord as an accompaniment to the octatonic scale, thus allowing for the presentation of the aggregate.

One can find a foreground instance of this technique in one of the songs from Schoenberg's Op. 12, "Jane Grey." Example 9 reproduces mm. 31-36 of that song. An analytical reduction of the passage is given as example 10. Here, Schoenberg uses an entire cycle of dominant-ninth chords (on F-sharp, A, E-flat, and C) to prolong the dominant of F. The latter is presented on the second half of $\mathrm{m} .32$, and the prolonging ninth chords from $\mathrm{mm}$. 33 to 36 . It is interesting to note that the vocal line from $\mathrm{m}$. 34 is built on the same octatonic scale as the accompaniment, with the exception of only one note: the A-flat on the last beat of m. 35 .

Let us now expand on this basic idea and have two notes of the lower diminished seventh chord presented simultaneously with the upper one. The results are "double-dominants," or dominants in two keys, at a distance of either a minor third or a tritone, as in example 11 . The example shows hexachordal double dominants in G/E, G/D-flat, G/B-flat, E/D-flat, E/B-flat, and D-flat/B-flat.

If we now delete the minor ninth of one of the two superimposed ninth chords, we get a sonority consisting of a major-minor seventh chord and a note belonging to the lower diminished seventh chord, or, following another point of view, a sonority consisting of three notes of one diminished seventh chord and two notes of another one, as in example 12. This type of sonority will now be called "combination chord."

The note which does not belong to the dominant seventh chord may be presented either as an added note or as a new bass. In the first case, as long as the two semitonally related elements of the sonority are not presented as a minor ninth, the root of the major-minor seventh would normally be understood as the root of the pentachord, with potential to function as a dominant. In the second case, the extra note's potential to become a dominant is realized only if the composer chooses to resolve the sonority accordingly. Of course, the final interpretation will rely mostly on voice leading.

All these sonorities are instances of important six- and five-note subsets of the octatonic collection. They are used by Richard Strauss at different places in the third scene of Salome, including the transition between the first and second part of Salome's three-part aria. This transition contains a striking outburst by Salome, which is the most intensely chromatic and tonally ambiguous event in the opera 


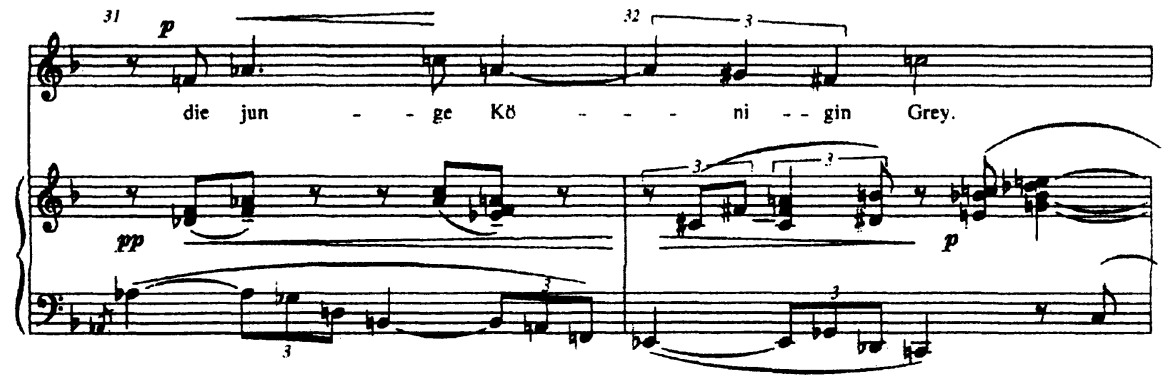

3.3

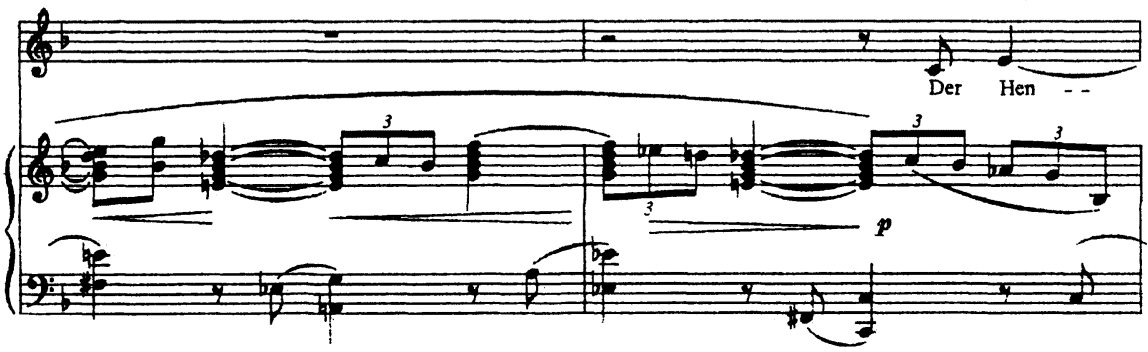

36

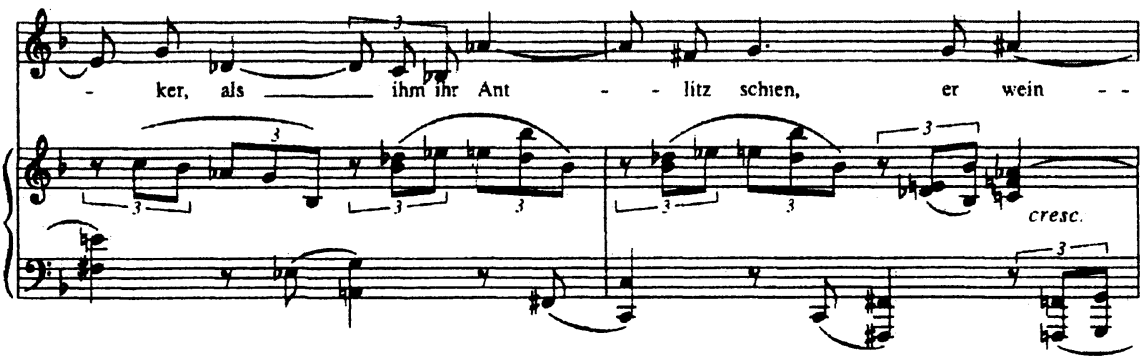

Example 9: Schoenberg, "Jane Grey," Op. 12/1, mm. 31-36. Copyright 1920 by Universal Edition. Copyright renewed. All rights reserved. Used in the territory of Canada by permission of European American Music Distributors Corporation, sole Canadian agent for Universal Edition.

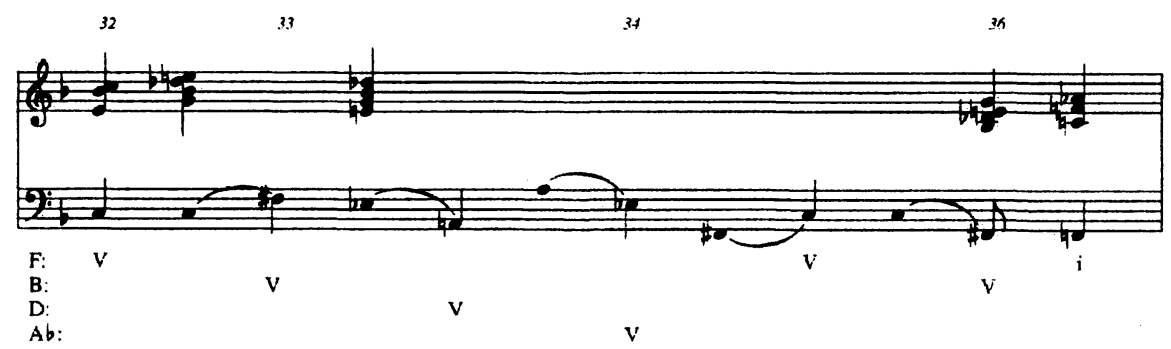

Example 10: Schoenberg, "Jane Grey," Op. 12/1, mm. 32-36; harmonic analysis. 


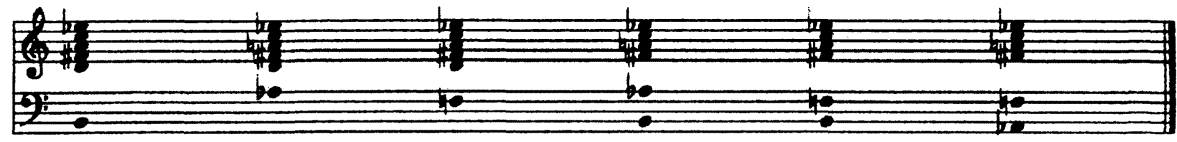

Example 11: "Double dominants".

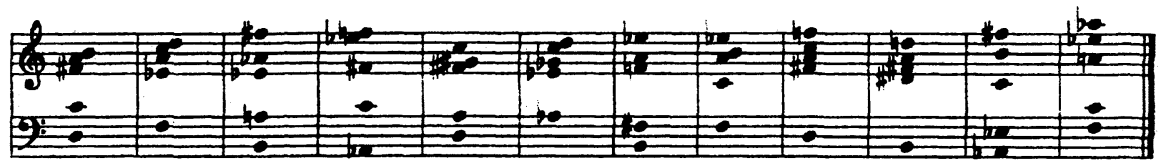

Example 12: Pentachordal combination chords.

thus far. Motives are piled one upon the other over a succession of chromatic sonorities and a potentially functional bass line. After an upbeat $\mathrm{C}$, the bass distorts the opening interval of one of the main motives of the opera, often called the "Bussprediger" motive, moving deceptively to F-sharp (instead of $\mathrm{G})$, and creating both a motivic tritone and a very clear example of chromatic displacement of an expected tone. This technique, which can be applied to one note, to a whole chord, or even to an entire phrase, has long been recognized as a typical Straussian device, especially at cadences; here the distortion is both of an established motive (descending fourths) and of an expected V-I cadence (in F major). Tenschert gives a number of examples of this technique. ${ }^{16}$

Notwithstanding its highly chromatic character, this passage can be explained in tonal terms. The outburst is a good example of organic octatonicism. It can be interpreted as the result of a series of simple transformations applied to a standard tonal model. The octatonic sonorities and connections are thus quite different from the surface decorations of the example by Messiaen presented earlier.

An interpretation of the harmony of Salome's outburst is given in example 13. In example $13 a$, a sequence connects the dominant of D-flat major and its tonic. In example $13 \mathrm{~b}$, the minor triads of $13 \mathrm{a}$ are enhanced with added sixths, the C-major triad is presented in its first inversion and the final dominant seventh in second inversion, for voice-leading reasons. In example 13c, two chromatic neighbours are added to each of the four-tone chords created in $13 \mathrm{~b}$ and only the bass $\mathrm{E}$ of the C-major triad is preserved. The chord pairs labelled $\mathrm{A}$ and $\mathrm{B}$ are hexachordal octatonic subsets. The first one (labelled A) contains

16Roland Tenschert, "Die Kadenzbehandlung bei Richard Strauss," Zeitschrift für Musikwissenschaft 8 , no. 3 (1925): 161-82. Three of Tenschert's examples of chromatic displacement come from Salome. They involve mm. $102^{6-7}, 360^{6}-61^{1}$, and $361^{5-6}$. His examples are of surface phenomena. Salome, however, is filled with such displacements, not only at the surface, but sometimes also at deeper structural levels. 


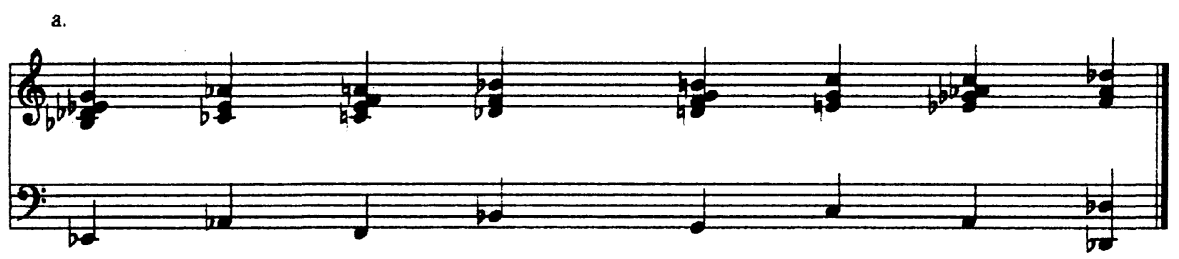

b.

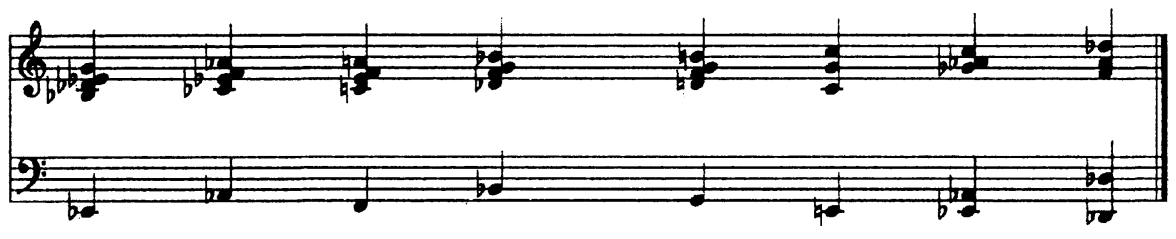

c.
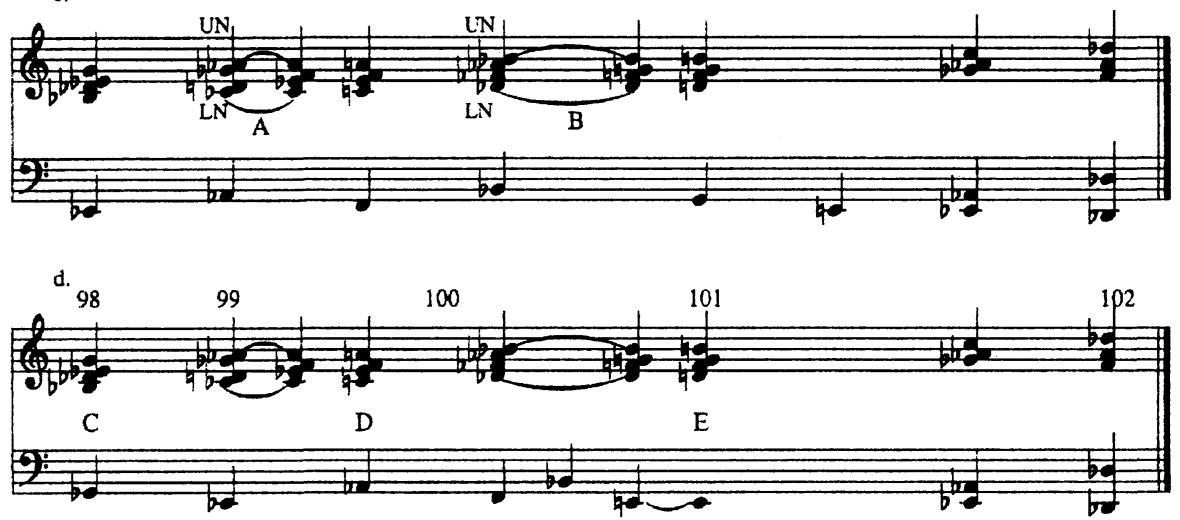

Example 13: Salome, 98-102; generative model.

two notes of the diminished seventh chord (C, E-flat, F-sharp, A) and the entire (D, F, A-flat, B), while the other (labelled B) contains two notes of (D, F, A-flat, B) and the entire (D-flat, E, G, B-flat). Note also that, within chord pairs A and $\mathrm{B}$, the neighbour chords are related by the octatonic operator $\mathrm{T} 9$ to their chords of resolution.

In the next transformational stage, the first three bass notes are moved one position to the right, the $\mathrm{G}$ is deleted, and the $\mathrm{E}$ is moved two positions to the left. Finally, the first sonority receives a bass G-flat. The result, which is also Strauss's harmony for the passage, is shown in example 13d.

The last move, i.e., the addition of the new bass note G-flat, has two advantages: it respects the general intervallic pattern of the bass and creates an octatonic combination chord (G-flat, E-flat, G, B-flat, D-flat) (labelled C). But the moves in the bass have generated other such combination chords. The chord over A-flat (labelled D) has two elements of (D, F, A-flat, B) and three of (C, E-flat, F-sharp, A), while the chord over the held E (labelled E) has two 
elements of (D-flat, E, G, B-flat) and three of (D, F, A-flat, B). It is particularly interesting to note the thoroughness with which Strauss explores the possibilities of such combinations: he never uses the same construction twice. ${ }^{17}$

The beginning of this transition was analyzed in an altogether different manner by German musicologist Herbert Windt in $1924 .{ }^{18}$ Windt interprets the first two chords (and, seemingly, the entire transition) in F major. His analysis is worth quoting at length.

Basically, everything is in pure $\mathrm{F}$ major. The fourths of Jochanaan's motive furnish the material for the first chord of the first measure: the fourth-chain A, D, G, C, F. Except for G, Strauss transposes all members of $F$ major by a semitone upwards: A-sharp, D-sharp, G, C-sharp, F-sharp. The inversion of this produces ascending fifths: F-sharp, C-sharp, G, D-sharp, A-sharp. After the upbeat C, the sudden arrival of this altered sonority seems foreign and astonishing... ${ }^{19}$

Windt thus sees the first chord as an alteration of a chord in fourths, itself a verticalization of Jochanaan's fourths motive. Interestingly enough, this astonishing interpretation also uses transformations. However, those are certainly not simple tonal transformations and the resulting picture, which is actually not very far from recent atonal theory, does not seem to suit the general tonal context of this particular work.

Chords A and B of example 13 belong to the same family of sonorities as those of example 11. Chords C, D, and E of the same example are pentachordal combination chords.

A magnificent example of the utilization of these sonorities is found between 766 and 774, under Salome's words: "Seine Augen sind vor allem das Schrecklichste. Sie sind wie die schwarzen Höhlen, wo die Drachen hausen!" A harmonic reduction of this passage is given in example $14 .{ }^{20}$

At 766, the chord (E-flat, G, B-flat, D-flat), which was reached through chromatic voice-leading, receives the bass F-sharp. This is of course an instance of a pentachordal combination chord such as those found in example 12. It contains three members of (G, B-flat, D-flat, E) and two of (F-sharp, A, C, E-flat). ${ }^{21}$ As shown in example 14, B-flat, G, and D-flat are held for the following measures. On the downbeat of 767 , the note $\mathrm{A}$ is added to F-sharp and E-flat to form a hexachordal sonority of the type presented in example 11.

17 If one labels chord (C, E-flat, F-sharp, A) as $x$, chord (D-flat, E, G, B-flat) as y, and chord (D, F, A-flat, $B$ ) as $z$, chord $C$ of example $13 d$ is built from elements of $x$ and $y$, chord $D$ from elements of $x$ and $\mathrm{z}$, and chord $\mathrm{E}$ from elements of $\mathrm{y}$ and $\mathrm{z}$. All combinational possibilities have been used.

18Herbert Windt, "Richard Strauss und die Atonalität," Die Musik 16 (1924): 642-53.

19Da ist im Grunde alles reines F-dur. Aus den Quarten des aufsteigenden Jochanaan-Motivs ergibt sich des Material des allerersten Akkordes im ersten Takt: die Quartenfolge a, d, g, c, f. Bis auf g alteriert Strauss alle Töne des F-dur um einen Halbton aufwärts, also ais, dis, g, cis, fis. Ihre Umkehrung ergibt also Quinten aufwärts: fis, cis, g, dis, ais. Zu dem Auftakt $\mathrm{c}$ wirkt der unvermittelte Einsatz dieses alterierten Akkordes derart fremd und überraschend ... Ibid., 648.

20 Measures are numbered in the following way: 761 is the first measure of rehearsal number 76 , i.e., the measure that has as its left barline the barline that carries number 76 .

21 In example 14, the notes of the two source diminished seventh chords have been notated on different staves for clarity's sake. 


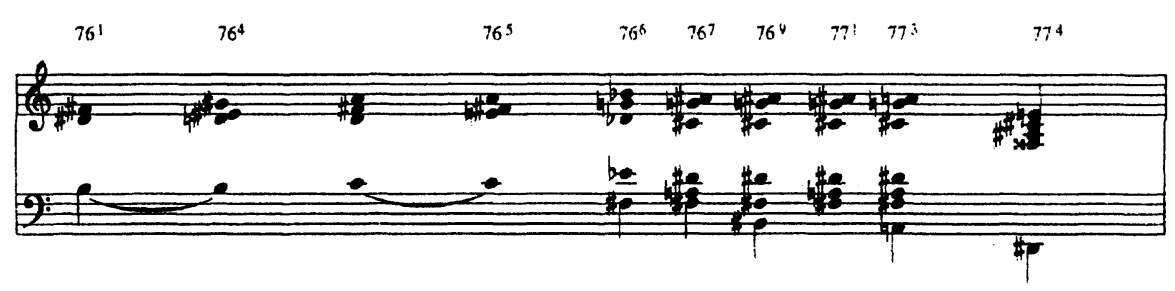

Example 14: Salome, 76-77+4; harmonic reduction.

At 769, the held (C-sharp, G, A-sharp) is combined with (B-sharp, D-sharp, F-sharp) to create another hexachordal sonority. ${ }^{22}$ From 77 to 773 , another hexachordal "double dominant" sonority is held. The only note of the bass diminished seventh chord that remains to be used is D-sharp. It comes at 774, but this time one of the diminished seventh chords, (F-double sharp, A-sharp, C-sharp, E), is complete and the sonority is a dominant ninth chord in the key of G-sharp.

This type of situation is repeated at 812 . There, one finds a dominant ninth chord in the key of C. At 813, this is transformed into the combination chord (D-flat, E, F, A-flat, C-flat), ${ }^{23}$ itself held for two measures. At 817, the ninth chord of 812 , this time with a bass $\mathrm{E}$, is reached through chromatic voice leading.

\section{Conclusions}

It should by now be clear that traditional chromatic tonal procedures can create a great variety of octatonic situations. Before the second half of the nineteenth century, most composers were unaware of, or unattracted by these octatonic possibilities. In Salome, Strauss seems to have realized that the octatonic patterns that kept surfacing in the type of progressions that he was using could be used more deliberately in order to create a very special type of chromatic sound. This sound was quite different from that of the other symmetrical collection that he knew, i.e., the whole-tone scale. The composer seems to have decided to use octatonic chromatic tonality mainly for the characterization of Salome's world (this is why Herod's attempts to seduce his niece often use this type of music), reserving other types of chromaticism for Herod and the Jews. ${ }^{24}$ However, as the century progressed and as interest in symmetrical organization grew, octatonic patterns and harmonic structures came to be used more and more consciously. This trend reached its apogee in the works of Stravinsky and Bartók.

22 At 769 , the vocal score of Salome has B-natural in the bass. This is an error. The full score has a clear B-sharp.

23 With a suspension D.

24 See Jean-Michel Boulay, Monotonality and Chromatic Dualism in Richard Strauss's Salome (Ph.D. diss., University of British Columbia, 1992), 3-6. 


\begin{abstract}
In this paper, the author looks at the relationship between octatonic structures and chromatic harmony. The discussion concentrates on two major aspects of late-tonal octatonicism: the use of alternative bass tones for the diminished seventh chord and the development of these sonorities into hexachordal and pentachordal combination chords. A number of late nineteenth-century and early twentieth-century chromatic passages are analyzed. Complex harmonies in chromatic passages are explained by formulating reductive models comprised of simpler, octatonic constructs.
\end{abstract}

